\title{
Early Recovery Protocols Effect the Opioid Prescriptions at Discharge After Major Urologic Cancer Surgery
}

Kevin M. Carnes $\mathrm{MD}^{1}$, Ashar Ata $\mathrm{PhD}^{2}$, Theodore Cangero ${ }^{3}$ and Badar M. Mian MD ${ }^{1^{*}}$

1. Division of Urology, Albany Medical College, Albany NY 12208

2. Department of Surgery, Albany Medical College, Albany NY 12208

3. Department of Information Services, Albany Medical College, Albany NY 12208

*Corresponding author: Badar M. Mian, MD mianb@amc.edu

Albany Medical College, Division of urology, 25 Hackett Blvd., Albany NY 12208 


\begin{abstract}
Introduction

Early recovery after surgery (ERAS) protocols are designed limit the use of opioids during in-patient stay to facilitate recovery and early discharge. However, there are conflicting reports of opioids prescribed at discharge to these patients. We wished to evaluate the effect of early recovery efforts on the opioid prescriptions given at discharge after major urologic cancer surgery.
\end{abstract}

\title{
Methods
}

We reviewed opioid prescription data from patients discharged from our facility after major urologic cancer surgery from 2016 to 2018, including cystectomy, nephrectomy (total, partial) and prostatectomy. The opioid prescriptions were normalized to hydrocodone- $5 \mathrm{mg}$ tablet equivalents. Multivariable analysis was performed to evaluate the effect of various factors on opioid prescriptions at discharge.

\section{Results}

409 patients met the inclusion criteria, with 207 without ERAS and 202 on ERAS protocol. Potent opioid (oxycodone or hydrocodone) use was reduced from $92 \%$ to $43 \%$ and tramadol use increased from $8 \%$ to $57 \%(p<0.001)$. Following ERAS, we noted reduction in opioid prescriptions for prostatectomy $(30 \%, p<$ $0.001)$, cystectomy $(27 \%, p=0.02)$ and all nephrectomy procedures $(32 \%, p<0.001)$. On multivariable analysis for each procedure, ERAS protocol was a significant predictor of opioid prescriptions at discharge.

\section{Conclusions}

A significant decrease in the opioid prescriptions given at discharge was noted after major urologic cancer surgery with the use of ERAS protocols. There was a significant shift towards the use of less potent opioids. These findings provides a benchmark for further interventions and reduction in the outpatient opioid prescriptions after major urologic surgery. 
medRxiv preprint doi: https://doi.org/10.1101/2020.05.24.20112243; this version posted May 25, 2020. The copyright holder for this preprint (which was not certified by peer review) is the author/funder, who has granted medRxiv a license to display the preprint in perpetuity. It is made available under a CC-BY-NC-ND 4.0 International license .

\section{Introduction}

An estimated 50 million surgical procedures are performed in the US annually and opioid analgesics are routinely prescribed for these patients for post-operative pain control. ${ }^{1,2}$ The risk of opioid use disorder, prescription misuse, and deaths resulting from overdose has been a growing problem over the last two decades. ${ }^{3}$ As of September 2018, more than 67,000 Americans had died of opioid related overdose in the prior 12 months. It is common to have excessive prescriptions of opioids after surgery, with nearly two thirds of patients reporting leftover opioids following urological surgery, which may serve as the potential source of opioid abuse. ${ }^{4}$ Even a short exposure to opioids in opioid-naïve patients following minor or major surgery has been associated with de novo habitual or persistent use of opioids in 5-30\% of patients. ${ }^{5,6}$

Multidisciplinary, collaborative efforts have been undertaken at many centers to develop early recovery after surgery (ERAS) protocols in conjunction with dedicated members of anesthesia team and nursing staff. The ERAS protocols limit the in-patient use of opioids in order to minimize bowel dysfunction, expedite recovery and early discharge from the hospital. While it may seem intuitive that the opioid prescriptions given at discharge should also have, this has not been the case. To the contrary, some studies have reported that patients managed under ERAS protocol may be receiving similar or higher opioid prescriptions at discharge. ${ }^{7}$ The association between opioid prescription at discharge and ERAS protocol has not been studied well in urologic cancer surgery. Our goal was to study whether the implementation of ERAS protocols had affected the practice of opioid prescriptions given at discharge after major urologic cancer surgeries at our center.

\section{Materials and Methods}

We reviewed the hospital medical records of patients undergoing robotic radical prostatectomy, open or robotic radical nephrectomy, open or robotic partial nephrectomy, and open radical cystectomy at our center from 2016 to 2018. The main inclusion criteria were the availability of opioid prescriptions data at discharge, including the type of medication and number of tablets prescribed. Because electronic prescription documentation was not mandatory during the entire study period, we included only those patients who had an electronically documented opioid prescription. Patients who may have received a handwritten prescription or a mention of the prescription without details in the discharge paperwork could not be included because we could not confirm the strength or the tablet count of the prescription. Due to the similarities in the incisions, the post-operative recovery protocols and discharge instructions, patients undergoing total nephrectomy, partial nephrectomy and nephroureterectomy were included in the nephrectomy group, and subdivided into either open or robotic, depending upon the approach.

We reviewed the discharge opioid prescription pattern before and after initiating the ERAS protocol for nephrectomy, prostatectomy, and cystectomy which were implemented in early to mid-2017. A brief description of the preferred analgesic medications used in ERAS protocols for various procedures is provided in supplementary materials (Table A). The discharge instructions recommended using acetaminophen and/or ibuprofen, but no other medications were prescribed. While medications such as 
medRxiv preprint doi: https://doi.org/10.1101/2020.05.24.20112243; this version posted May 25, 2020. The copyright holder for this preprint (which was not certified by peer review) is the author/funder, who has granted medRxiv a license to display the preprint in perpetuity. It is made available under a CC-BY-NC-ND 4.0 International license .

gabapentin or pregabalin were used for some patients as part of ERAS protocol, patient were not discharged with these medications. In order to identify any patients who may have required additional opioid prescriptions as an outpatient, we reviewed the outpatient electronic medical record system of patients on ERAS protocols for 30 days after discharge. We cataloged all the phone calls made by the patients to the office and any outpatient opioid prescriptions. Due to a change in outpatient medical record system, we could not collect similar data for patients treated before ERAS protocols. The additional outpatient opioid prescription strength and dose was at the discretion of the prescriber.

We conducted an interview survey of twelve prescribers (residents and PAs), who were responsible for discharge prescriptions, to elicit descriptive responses regarding their opioid prescribing patterns including the rationale for the amount and type of medications used is provided in the supplementary data (Table B).

Primary outcomes of interest were the number of standardized opioid tablets and the type of medications prescribed at discharge. The medications prescribed included hydrocodone with acetaminophen, oxycodone (with or without acetaminophen) and tramadol. While morphine milligram equivalents (MME) are often used to standardize the opioid prescriptions, we elected to standardize the opioid dose into standardized tablet counts because a tablet is a more clinically relevant unit for the prescribers. MME data is provided in supplementary documents. Each prescription was converted into total MME and then into standardized tablet count of hydrocodone-5 mg equivalents. We used the standardized tablet count for data analysis and have provided MME data in supplementary data (Table C). The mean (standard deviation, $\pm S D$ ) number of standardized tablets prescribed for each procedure were compared before and after ERAS.

Categorical variables were described and compared between before and after ERAS implementation periods using Chi-square tests and Fisher's Exact tests. Continuous variables were compared via t-tests, Wilcoxon rank sum tests. Our outcome of interest was hydrocodone-5 mg equivalents each tablet and distributed on a continuous scale. Multivariable adjustment was done via linear regression and the adjusted effects, and $95 \%$ confidence intervals were reported. Analysis was performed using all available data for each surgical procedure. Statistical software STATA 15.0 was used for analysis and statistical significance was assessed based on alpha of 0.05 and $95 \%$ confidence interval of the differences.

\section{Results}

Of the 409 patients undergoing major urologic procedures, 207 (51\%) had surgery before ERAS and 202 (49\%) after ERAS protocols were initiated. Robot-assisted laparoscopic approach was used in 285 cases, with 158 (55\%) procedures before implementing ERAS protocol. The patient characteristics are outlined in Table 1. There was no difference in the age, gender, race and pre-operative opioid use amongst the group. There was a significant difference in the opioid medications prescribed. After ERAS, tramadol was prescribed at a significantly higher rate than hydrocodone or oxycodone $(p<0.001)$. These medications were standardized into hydrocodone- $5 \mathrm{mg}$ equivalent tablets for further analysis. 
medRxiv preprint doi: https://doi.org/10.1101/2020.05.24.20112243; this version posted May 25, 2020. The copyright holder for this preprint (which was not certified by peer review) is the author/funder, who has granted medRxiv a license to display the preprint in perpetuity. It is made available under a CC-BY-NC-ND 4.0 International license .

There was a significant decline in the mean opioid tablets prescribed at discharge for each procedure after initiating ERAS protocols (Figure 1). For open radical and partial nephrectomy procedures (>90\% with flank incision), the mean opioid tablets decreased by $38.2 \%(49.7 \pm 15.4$ to $30.7 \pm 18.5, p<0.001)$ and for robotic nephrectomy procedures, the mean opioid tablets decreased by $34.6 \%$ (37.6 \pm 14.6 to $24.6 \pm 14.3,<0.001)$. For patients undergoing prostatectomy, $30 \%(33.0 \pm 9.1$ to $23.1 \pm 8.3, p<0.001)$ reduction in the mean opioid tablet count was noted. Opioid prescriptions given at discharge after cystectomy decreased by $27.2 \%$ (39.0 \pm 17.1 to $28.4 \pm 12.9, p=0.02)$.

We performed multivariate analysis for each of the 4 procedures individually as well including all procedures as variable. After controlling for age, gender, race and pre-operative opioid use, ERAS protocol was associated with most significant reduction in opioid prescriptions given at discharge, followed by type of surgery (Table 2). Increasing age was also associated with fewer opioid prescriptions. With open nephrectomy as the reference, other procedure types were associated with a higher rate of reduction in opioid prescriptions given at discharge. The multivariable analysis for individual procedures is provided with the supplementary data (Table D-F).

The opioid formulations prescribed at discharge included hydrocodone with acetaminophen, oxycodone, and tramadol (Figure 2). Before ERAS protocol, $91 \%$ of patients received either hydrocodone (24.7\%) or oxycodone (67.6\%). After ERAS protocol, the use of tramadol increased from $9 \%$ to $51 \%(p<0.001)$.

Upon reviewing the outpatient medical records of 202 patients on ERAS protocols, we identified phone calls from 38 (18.8\%) patients within 30 days of discharge. Most of the call were related to discomfort due to Foley catheter, bladder spasms, hematuria, and GI issues. Of these, 13 (6.6\%) patients were prescribed 23.0 hydrocodone- 5 mg equivalent tablets (range 10-45 tablets), and 11 of 13 patients received hydrocodone or oxycodone. All 13 patients requiring additional opioids as outpatient had undergone either an open nephrectomy procedure (8 patients) or robotic nephrectomy procedure (5 patients).

\section{Discussion:}

Nearly 200 million opioid prescriptions are dispensed per year in the United States. ${ }^{8}$ The rate of opioid prescription is the highest amongst certain specialties including pain medicine (48.6\%), surgery (36.5\%), and physical medicine \& rehabilitation (35.5\%). ${ }^{9}$ In addition to illicit drugs, opioid prescriptions given by providers are a major contributor to the opioid abuse epidemic. Nearly $40 \%$ of opioid overdose-related deaths occur due to prescribed opioids. ${ }^{10}$ Among patients diagnosed with opiate dependence, $80 \%$ had received an opioid prescription prior to their abuse diagnosis and $51 \%$ had a family member who had an opioid prescription. ${ }^{11}$ In a recent study of major procedures involving kidney or prostate in 155 patients, Theisen et al reported an average of 26 oxycodone-equivalent (or 39 hydrocodone-equivalent) tablets were prescribed per patient at discharge, $60 \%$ of which remained unused. ${ }^{12}$ Thus, the impact of opioids prescribed by medical professionals cannot be overstated. It's essential to identify the trends and factors associated with opioid prescriptions given for use at home at hospital discharge. The ERAS 
medRxiv preprint doi: https://doi.org/10.1101/2020.05.24.20112243; this version posted May 25, 2020. The copyright holder for this preprint (which was not certified by peer review) is the author/funder, who has granted medRxiv a license to display the preprint in perpetuity. It is made available under a CC-BY-NC-ND 4.0 International license .

protocols are being utilized at many centers in order to hasten recovery through reduced use of opioids during the in-patient recovery period. We wished to determine whether the opioid reduction measure used for in-patient recovery had an impact on opioid prescriptions given at discharge.

In our 409 patients undergoing abdominal surgery for urologic cancers (open or robotic), we noted a significant, $27 \%$ to $38 \%$, decrease in opioid prescriptions for various procedures. On multivariate analysis, ERAS protocol was independently associated with decrease in outpatient opioid prescriptions. The largest decrease after initiating ERAS protocol was noted in the open nephrectomy group (from 45 to 24 hydrocodone-equivalent tablets), while a smaller, but significant, decrease was noted in the robotic-assisted prostatectomy group (from 33 to 23 hydrocodone-equivalent tablets).

It's important to make a distinction between opioids used during inpatient stay which are dictated by the ERAS protocol and the opioid prescriptions given at discharge. The ERAS protocols are very prescriptive about use of medications during hospital stray and usually include some educational material and/or some counseling by the nurse about opioid use. However, the ERAS protocols typically did not address the opioid prescriptions given at discharge. We reviewed several different ERAS protocols for abdominal/pelvic surgery from other specialties and centers, and did not find any specific directions for opioids prescriptions to be given at discharge. It's interesting to note that most of the measures listed under ERAS protocols, including medications, have been used by various physicians at their discretion. Formalizing the ERAS protocols, with the inclusion surgeons, anesthesiologists and nurses, brings everyone's focus on reducing inpatients opioid use for early discharge. It necessitates daily discussion and education of the patients and prescribers about opioids, bringing a cultural shift within the medical team. It's like that this enhanced focus on reducing opioids during recovery resulted in reduction of opioid prescriptions given at discharge for our patients

There are conflicting reports in the literature about opioid prescriptions at discharge for patients managed with ERAS protocols. Brandal et al reviewed colorectal surgery procedures and reported that there was no decrease in the opioid prescriptions at discharge when compared to the pre-ERAS cohort. Unexpectedly, even the subgroup with low pain scores during hospitalization and no perioperative opioid use were discharged with similarly high rate of opioid prescriptions. ${ }^{13}$ Another study of the opioid prescribing patterns after colorectal surgery in 2018 demonstrated that while ERAS protocol resulted in a shorter hospital stay, these patients were prescribed significantly more opioids at discharge than the patients not on the ERAS protocol (61.4 vs. 48.4 hydrocodone- 5 mg equivalents). ${ }^{7}$ These surprising findings suggest that for many ERAS protocols, the emphasis remains on early discharge from the hospital and not necessarily on reducing opioid dissemination. In a report from 2019, Patel et al implemented standardized post-operative prescribing guidelines (separate from the inpatient recovery guidelines) which resulted in reduced post-prostatectomy opioid prescriptions from $224 \mathrm{MME}$ to 120 MME (from 45 to 24 hydrocodone- 5 mg equivalents) which is similar to opioids prescribed to our prostatectomy patients on ERAS (from 33 to 23 tablets) at discharge. ${ }^{14}$ Interestingly, despite minimally invasive prostatectomy procedure, their pre-intervention patients were receiving relatively large amount of opioid prescriptions. In these studies referenced above, the invasiveness of the procedure and early discharge did not correlate with opioid prescribing patterns. In our cohort, we demonstrated a 
medRxiv preprint doi: https://doi.org/10.1101/2020.05.24.20112243; this version posted May 25, 2020. The copyright holder for this preprint (which was not certified by peer review) is the author/funder, who has granted medRxiv a license to display the preprint in perpetuity. It is made available under a CC-BY-NC-ND 4.0 International license .

significant decrease in opioid prescriptions after discharge for both the open, radical as well as minimally invasive cancer surgery of kidney, bladder and prostate.

One of the concerns with limiting opioid prescriptions at discharge is that it could result in poor pain control, excessive number of phone calls to the office and need for additional opioid prescriptions. While nearly $18 \%$ of patients made a phone call to office, just over $6 \%$ needed additional opioid prescriptions, primarily in open nephrectomy patients. Further, 9 of the 13 patients requiring additional opioids were age 55 or younger. While we do not have comparative data, the age group and opioid requirements are in line with the publishes literature. These findings identify a subgroup of patients that could benefit from adjustments in post-operative instructions and pain medications such as opioid doses and additional medications such as gabapentin or topical analgesics.

Our interview survey of the prescribers revealed several informative aspects of their prescribing patterns shown in supplementary data (Table B). All prescribers were aware of the opioid abuse crisis and affirmed that they had been prescribing very few and less-potent opioids at discharge. Our ERAS protocols listed tramadol as the preferred oral opioid to be used during hospitalization. Most prescribers viewed tramadol to be associated with a lower potential risk of abuse. This view likely resulted in over 5 fold increase in tramadol and $88 \%$ reduction in hydrocodone prescriptions given at discharge for all procedures. When asked about using tablet counts and morphine milligram equivalents (MME) to decide on the number and strength of the prescription, none of the twelve prescribers have ever used MME in practice. We believe that the opioids data should be presented in tablet equivalents because it is clinically more familiar and translatable unit for the readers (MME data is provided in supplementary table C).

Unused opioids that are usually kept by the patients after surgery pose a significant risk of opiate misuse. Cabo et al found that $79 \%$ of patients who received an opiate prescription after urological surgery had leftover medication. ${ }^{15}$ In another study, pharmaceutical opioid diversion was associated with $63 \%$ of opioid-related deaths, with diversion prevalence being the highest among the $18-24$ year old decedents. ${ }^{16}$ In the studies by Patel and Thiessen, robotic prostatectomy patients were given 24 and 39 hydrocodone $-5 \mathrm{mg}$ equivalent tablets, of which $68 \%$ and $60 \%$ remained unused, respectively. ${ }^{12,14}$ Our robotic prostatectomy patients received 23 hydrocodone- $5 \mathrm{mg}$ equivalent tablets. While we do not have that specific data for our cohort, it's likely that the rate of unused tablets would be similar.

To our knowledge, this is one of the only studies of urologic cancer surgery demonstrating a reduction in opioid prescriptions at discharge for patients managed with ERAS protocol after our most frequent major surgery (both open and robotic). Our study has other limitations which are associated with a retrospective analysis. We included only those cases where complete information about the opioid dose and strength was documented. It's possible that the excluded patients could have received opioid prescription at discharge or after discharge through another physician or outpatient clinic. The reduction in opioid prescriptions given at discharge for ERAS patients did not results in an excessive need for additional outpatient prescriptions. However, the data for the non-ERAS group was unavailable and incomplete so that a meaningful comparison between the groups was not possible. 
While we demonstrated a reduction in opioid prescriptions written at discharge, published reports suggest that further reduction may be possible since up to $60 \%$ of prescribed opioids may remain unused. ${ }^{12,14}$ Further efforts, such as adjusting the ERAS protocol and educational materials, made in reducing the dissemination of excessive prescription opioids and abuse potential are of utmost importance in curbing the opioid abuse epidemic.

\section{Conclusions:}

We noted a significant decrease in opioid prescriptions given at discharge after major, open or robotic, urologic surgery for patients managed with ERAS protocol. There was a significant reduction not only in the total opioid dose but also significant shift towards the use of less potent opioid medications. It's essential to continue all efforts to mitigate the harmful effects of excessive opioid prescriptions. This data will serve as a benchmark to develop further interventions to reduce opioid prescriptions after urologic cancer surgery and limit the availability of the opioids in the community. 
medRxiv preprint doi: https://doi.org/10.1101/2020.05.24.20112243; this version posted May 25, 2020. The copyright holder for this preprint (which was not certified by peer review) is the author/funder, who has granted medRxiv a license to display the preprint in perpetuity.

\section{References}

1. Steiner, C. A., Karaca, Z., Moore, B. J. et al.: Surgeries in Hospital-Based Ambulatory Surgery and Hospital Inpatient Settings, 2014: Statistical Brief \#223. In: Healthcare Cost and Utilization Project (HCUP) Statistical Briefs. Rockville (MD): Agency for Healthcare Research and Quality (US), 2006

2. Hall, M. J., Schwartzman, A., Zhang, J. et al.: Ambulatory Surgery Data From Hospitals and Ambulatory Surgery Centers: United States, 2010. Natl Health Stat Report: 1, 2017

3. Manchikanti, L., Helm, S., Fellows, B. et al.: Opioid epidemic in the United States. Pain physician, 15: ES9, 2012

4. Bates, C., Laciak, R., Southwick, A. et al.: Overprescription of postoperative narcotics: a look at postoperative pain medication delivery, consumption and disposal in urological practice. J Urol, 185: 551, 2011

5. Barham, D. W., McMann, L. P., Musser, J. E. et al.: Routine Prescription of Opioids for Postvasectomy Pain Control Associated with Persistent Use. J Urol: 101097ju0000000000000304, 2019

6. Shah, A., Hayes, C. J., Martin, B. C. J. M. M. et al.: Characteristics of initial prescription episodes and likelihood of long-term opioid use-United States, 2006-2015. 66: 265, 2017

7. Gerrish, A. W., Fogel, S., Lockhart, E. R. et al.: Opioid prescribing practices during implementation of an enhanced recovery program at a tertiary care hospital. Surgery, 164: 674, 2018

8. Hoots, B., Xu, L., Kariisa, M. et al.: 2018 Annual Surveillance Report of Drug-Related Risks and Outcomes - United States, 2018

9. Levy, B., Paulozzi, L., Mack, K. A. et al.: Trends in Opioid Analgesic-Prescribing Rates by Specialty, U.S., 2007-2012. Am J Prev Med, 49: 409, 2015

10. National Center for Health Statistics Division of Vital Statistics. Mortality Data, vol. 2018, 2017

11. Shei, A., Rice, J. B., Kirson, N. Y. et al.: Sources of prescription opioids among diagnosed opioid abusers. Curr Med Res Opin, 31: 779, 2015

12. Theisen, K. M., Myrga, J. M., Hale, N. et al.: Excessive Opioid Prescribing After Major Urologic Procedures. Urology, 123: 101, 2019

13. Brandal, D., Keller, M. S., Lee, C. et al.: Impact of Enhanced Recovery After Surgery and OpioidFree Anesthesia on Opioid Prescriptions at Discharge From the Hospital: A Historical-Prospective Study. Anesth Analg, 125: 1784, 2017

14. Patel, H. D., Faisal, F. A., Patel, N. D. et al.: Effect of a prospective opioid reduction intervention on opioid prescribing and use after radical prostatectomy: results of the Opioid Reduction Intervention for Open, Laparoscopic, and Endoscopic Surgery (ORIOLES) Initiative. BJU Int, 125: 426, 2020

15. Cabo, J., Hsi, R. S., Scarpato, K. R.: Postoperative Opiate Use in Urological Patients: A Quality Improvement Study Aimed at Improving Opiate Disposal Practices. J Urol, 201: 371, 2019

16. Hall, A. J., Logan, J. E., Toblin, R. L. et al.: Patterns of Abuse Among Unintentional Pharmaceutical Overdose Fatalities. JAMA, 300: 2613, 2008 
medRxiv preprint doi: https://doi.org/10.1101/2020.05.24.20112243; this version posted May 25, 2020. The copyright holder for this preprint (which was not certified by peer review) is the author/funder, who has granted medRxiv a license to display the preprint in perpetuity.

It is made available under a CC-BY-NC-ND 4.0 International license .

Table 1. Patient characteristics of 409 patients undergoing urologic cancer surgery.

\begin{tabular}{|c|c|c|l|}
\hline & $\begin{array}{l}\text { Pre-Eras, N } \\
(\%)\end{array}$ & $\begin{array}{l}\text { Post-ERAS, N } \\
(\%)\end{array}$ & $p$ Value \\
\hline Gender & & & 0.13 \\
\hline Male & $160(77.3)$ & $143(70.8)$ & \\
\hline Female & $47(22.7)$ & $59(29.2)$ & \\
\hline Race & & & 0.80 \\
\hline White & $187(90.3)$ & $186(92.1)$ & \\
\hline Black & $12(5.8)$ & $9(4.5)$ & \\
\hline Others & $8(3.9)$ & $7(3.5)$ & \\
\hline Pre-op Narcotics & & & 0.10 \\
\hline No & $195(94.2)$ & $195(96.5)$ & \\
\hline Yes & $12(5.8)$ & $7(3.5)$ & \\
\hline $\begin{array}{l}\text { Opioid prescribed } \\
\text { at discharge }\end{array}$ & & & $<0.001$ \\
\hline Hydrocodone & $49(23.7)$ & $6(2.9)$ & \\
\hline Oxycodone & $140(67.6)$ & $93(46.0)$ & \\
\hline Tramadol & $18(8.7)$ & $103(51.0)$ & \\
\hline
\end{tabular}


medRxiv preprint doi: https://doi.org/10.1101/2020.05.24.20112243; this version posted May 25, 2020. The copyright holder for this preprint (which was not certified by peer review) is the author/funder, who has granted medRxiv a license to display the preprint in perpetuity.

It is made available under a CC-BY-NC-ND 4.0 International license .

Table 2. Multivariable analysis of the difference in opioid prescriptions given at discharge including all procedures

\begin{tabular}{|l|l|l|}
\hline & Difference $(95 \% \mathrm{Cl})$ & P value \\
\hline Gender & & \\
\hline Female & Reference & \\
\hline Male & $2.75(-0.81,6.32$ & 0.13 \\
\hline $\begin{array}{l}\text { Age (for every 1-year increase } \\
\text { in age) }\end{array}$ & $-0.17(-0.30,0.03)$ & 0.01 \\
\hline Race & & \\
\hline White & References & \\
\hline Black & $-0.60(-6.95,5.75)$ & 0.85 \\
\hline others & $-1.72(-9.25,5.80)$ & 0.65 \\
\hline Preop narcotics & & \\
\hline No & Reference & \\
\hline Yes & $4.14(-3.11,11.4)$ & 0.26 \\
\hline ERAS Protocol & & \\
\hline No & Reference & \\
\hline Yes & $-12.63(-15.51,-9.75)$ & $<0.001$ \\
\hline Procedure type & & \\
\hline Open Nephrectomy & reference & \\
\hline Robotic Nephrectomy & $-6.85(-10.86,-2.84)$ & 0.001 \\
\hline Prostatectomy & $-10.98(-15.30,-6.67)$ & $<0.001$ \\
\hline Cystectomy & $-4.84(-10.49,0.80)$ & 0.09 \\
\hline
\end{tabular}


medRxiv preprint doi: https://doi.org/10.1101/2020.05.24.20112243; this version posted May 25, 2020. The copyright holder for this preprint (which was not certified by peer review) is the author/funder, who has granted medRxiv a license to display the preprint in perpetuity.

\section{It is made available under a CC-BY-NC-ND 4.0 International license .}

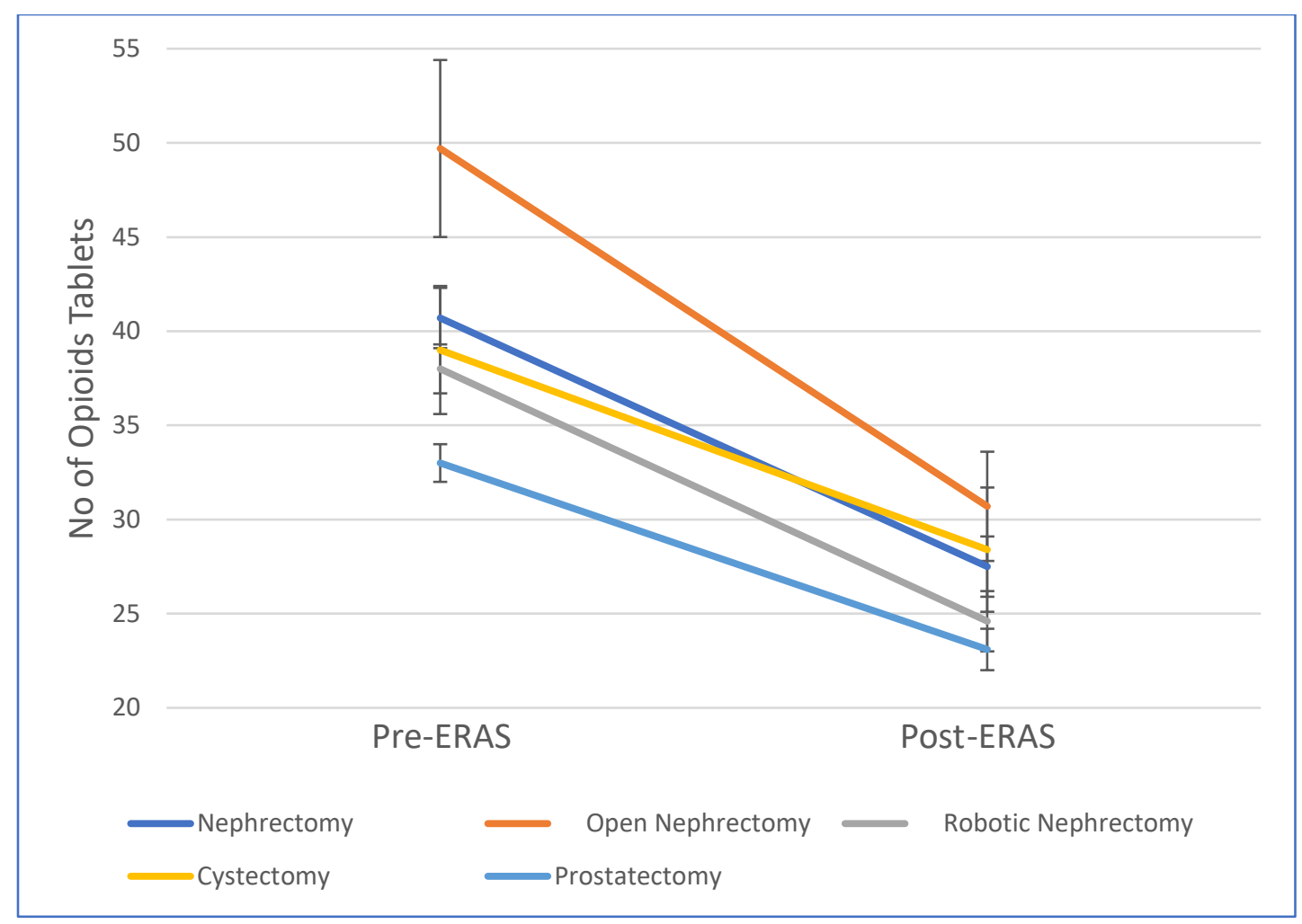

Figure 1. Reduction in opioid prescriptions in patients treated under the early recovery after surgery (ERAS) protocol. 
medRxiv preprint doi: https://doi.org/10.1101/2020.05.24.20112243; this version posted May 25, 2020. The copyright holder for this preprint (which was not certified by peer review) is the author/funder, who has granted medRxiv a license to display the preprint in perpetuity.

It is made available under a CC-BY-NC-ND 4.0 International license .

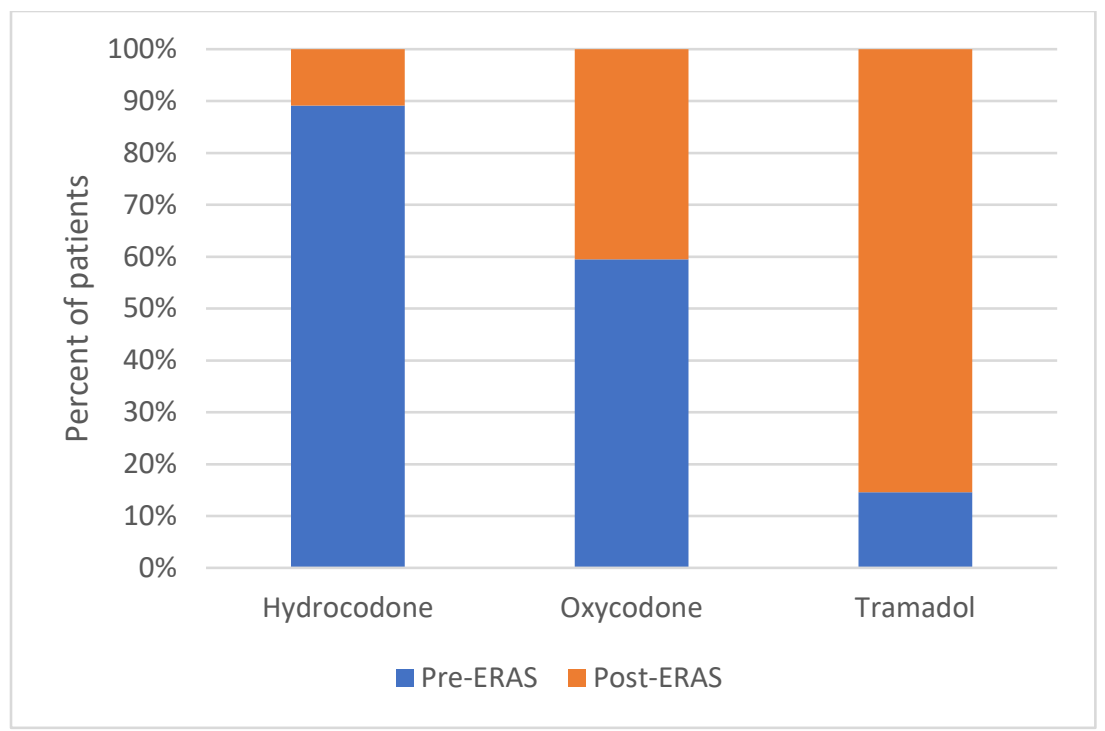

Figure 2. Change in the type of opioid medications prescribes at discharge from the hospital after ERAS protocol. 
medRxiv preprint doi: https://doi.org/10.1101/2020.05.24.20112243; this version posted May 25, 2020. The copyright holder for this preprint (which was not certified by peer review) is the author/funder, who has granted medRxiv a license to display the preprint in perpetuity.

It is made available under a CC-BY-NC-ND 4.0 International license .

\section{Supplementary Data}

Supplementary Table A. Analgesic medications used in the ERAS protocols.

\begin{tabular}{|c|c|c|c|c|}
\hline & Cystectomy, Open & Nephrectomy, Open & Nephrectomy, Robotic & $\begin{array}{l}\text { Prostatectomy, } \\
\text { Robotic }\end{array}$ \\
\hline $\begin{array}{l}\text { Pre-operative } \\
\text { medications* }\end{array}$ & $\begin{array}{l}\text { Acetaminophen } \\
\text { Celecoxib if GFR }>60 \\
\text { Pregabalin/Gabapentin } \\
\text { Scopolamine patch }\end{array}$ & $\begin{array}{l}\text { Acetaminophen } \\
\text { Celecoxib if GFR }>60 \\
\text { Pregabalin/Gabapentin } \\
\text { Scopolamine patch }\end{array}$ & $\begin{array}{l}\text { Acetaminophen } \\
\text { Celecoxib if GFR>60 } \\
\text { Pregabalin/Gabapentin } \\
\text { Scopolamine patch }\end{array}$ & $\begin{array}{l}\text { Acetaminophen } \\
\text { Celecoxib if GFR>60 } \\
\text { Pregabalin/Gabapentin } \\
\text { Scopolamine patch }\end{array}$ \\
\hline $\begin{array}{l}\text { Intra- } \\
\text { operative } \\
\text { medications*\# }\end{array}$ & $\begin{array}{l}\text { Propofol; Ketamine } \\
\text { Dexmedetomidine; } \\
\text { Lidocaine; Opioids } \\
\text { Ketorolac }\end{array}$ & $\begin{array}{l}\text { Propofol; Ketamine } \\
\text { Dexmedetomidine; } \\
\text { Lidocaine; Opioids }\end{array}$ & $\begin{array}{l}\text { Propofol; Ketamine } \\
\text { Dexmedetomidine; } \\
\text { Lidocaine; Opioids }\end{array}$ & $\begin{array}{l}\text { Propofol; Ketorolac; } \\
\text { Opioids }\end{array}$ \\
\hline $\begin{array}{l}\text { Regional } \\
\text { analgesia }\end{array}$ & TAP Catheters & Intercostal catheters & $\begin{array}{l}\text { Long acting } \\
\text { Bupivacaine }\end{array}$ & $\begin{array}{l}\text { Long acting } \\
\text { Bupivacaine }\end{array}$ \\
\hline $\begin{array}{l}\text { Post- } \\
\text { operative, } \\
\text { inpatient }\end{array}$ & $\begin{array}{l}\text { Acetaminophen; } \\
\text { Ibuprofen; } \\
\text { Tramadol; Oxycodone }\end{array}$ & $\begin{array}{l}\text { Acetaminophen; } \\
\text { Ibuprofen; } \\
\text { Tramadol; Oxycodone }\end{array}$ & $\begin{array}{l}\text { Acetaminophen; } \\
\text { Ibuprofen; } \\
\text { Tramadol; Oxycodone }\end{array}$ & $\begin{array}{l}\text { Acetaminophen; } \\
\text { Ibuprofen; } \\
\text { Tramadol; Oxycodone }\end{array}$ \\
\hline
\end{tabular}

*Not all medications are used in each patient; At the discretion of anesthesia team; Listed in the order of preference

\#All medications dosed for ideal body weight

TAP: Transversus Abdominis Plane 
medRxiv preprint doi: https://doi.org/10.1101/2020.05.24.20112243; this version posted May 25, 2020. The copyright holder for this preprint (which was not certified by peer review) is the author/funder, who has granted medRxiv a license to display the preprint in perpetuity.

It is made available under a CC-BY-NC-ND 4.0 International license .

Supplementary Table B. Descriptive responses to our interview survey from prescribers who were responsible for discharge medications.

\begin{tabular}{|c|c|}
\hline Question & Most frequent responses* \\
\hline $\begin{array}{l}\text { Are prescription opioids a } \\
\text { significant contributor to the } \\
\text { opioid crisis? }\end{array}$ & $\begin{array}{l}\text { Yes. } \\
\text { Significant. } \\
\text { Moderate. }\end{array}$ \\
\hline $\begin{array}{l}\text { Has your opioid prescription } \\
\text { pattern changed in the last } \\
\text { year? }\end{array}$ & $\begin{array}{l}\text { Yes. } \\
\text { Prescribing fewer tablets. }\end{array}$ \\
\hline Why? & $\begin{array}{l}\text { Patients don't seem to be requiring opioids } \\
\text { as in-patients. } \\
\text { Patients often have leftover tablets. }\end{array}$ \\
\hline $\begin{array}{l}\text { How do you decide which } \\
\text { medication to use? }\end{array}$ & $\begin{array}{l}\text { We have been using tramadol more } \\
\text { frequently in the hospital. }\end{array}$ \\
\hline Why? & $\begin{array}{l}\text { It's less addictive. } \\
\text { Avoids concerns over acetaminophen dose } \\
\text { limit since that is used first. }\end{array}$ \\
\hline $\begin{array}{l}\text { Are you familiar with morphine } \\
\text { milligrams equivalents (MME)? }\end{array}$ & $\begin{array}{l}\text { Yes. } \\
\text { Somewhat. }\end{array}$ \\
\hline $\begin{array}{l}\text { Do you sometimes use MME to } \\
\text { standardize the dosing of your } \\
\text { prescriptions? }\end{array}$ & Never \\
\hline $\begin{array}{l}\text { How do you decide on the } \\
\text { amount (tablets) of opioids? }\end{array}$ & $\begin{array}{l}\text { Based on in-patient pain control. } \\
\text { Out of habit. } \\
\text { Instructed by other team members. } \\
\text { Don't want the patient to run out of } \\
\text { medications. } \\
\text { Avoid phone calls. }\end{array}$ \\
\hline
\end{tabular}

*Listed in order of frequency 
medRxiv preprint doi: https://doi.org/10.1101/2020.05.24.20112243; this version posted May 25, 2020. The copyright holder for this preprint (which was not certified by peer review) is the author/funder, who has granted medRxiv a license to display the preprint in perpetuity.

It is made available under a CC-BY-NC-ND 4.0 International license.

Supplementary Table C. Reduction in opioid prescriptions after initiating ERAS protocols, standardized to morphine milligram equivalents*.

\begin{tabular}{|c|c|c|c|c|}
\hline & $\begin{array}{l}\text { Pre-ERAS, } \\
\text { Mean (SD) }\end{array}$ & $\begin{array}{l}\text { Post-ERAS, } \\
\text { Mean (SD) }\end{array}$ & Difference & P Value \\
\hline Nephrectomy & $203.5(77)$ & $137.5(92.5)$ & $-32.4 \%$ & $<0.001$ \\
\hline Open & $248.5(76)$ & $153.5(81.5)$ & $-38.2 \%$ & $<0.001$ \\
\hline Robotic & $190(73)$ & $123(71.5)$ & $-34.6 \%$ & $<0.001$ \\
\hline Cystectomy & $195(85.5)$ & $142(64.5)$ & $-27.2 \%$ & 0.02 \\
\hline \multirow[t]{2}{*}{ Prostatectomy } & $165(45.5)$ & $115.5(41.5)$ & $-30.0 \%$ & $<0.001$ \\
\hline & MME & MME & & \\
\hline Nephrectomy & 203.5 & 137.5 & & \\
\hline Open Nephrectomy & 248.5 & 153.5 & & \\
\hline $\begin{array}{c}\text { Robotic } \\
\text { Nephrectomy }\end{array}$ & 190 & 123 & & \\
\hline Cystectomy & 195 & 142 & & \\
\hline
\end{tabular}

*Data corresponds to Figure 1. 
medRxiv preprint doi: https://doi.org/10.1101/2020.05.24.20112243; this version posted May 25, 2020. The copyright holder for this preprint (which was not certified by peer review) is the author/funder, who has granted medRxiv a license to display the preprint in perpetuity.

It is made available under a CC-BY-NC-ND 4.0 International license.

Supplementary Table D. Multivariable analysis of the difference in opioid prescriptions given at discharge after all nephrectomy procedures

\begin{tabular}{|l|l|r|}
\hline & Difference $(95 \% \mathrm{Cl})$ & P value \\
\hline Gender & Reference & \\
\hline Female & $3.50(-1.06,8.05)$ & 0.13 \\
\hline Male & $-0.16(-0.34,0.02)$ & 0.08 \\
\hline $\begin{array}{l}\text { Age (every 1-year } \\
\text { increase in age) }\end{array}$ & & \\
\hline Race & References & \\
\hline White & $1.16(-7.80,10.13)$ & 0.79 \\
\hline Black & $-0.57(-11.01,9.87)$ & .91 \\
\hline others & & \\
\hline Preop narcotics & Reference & 0.56 \\
\hline No & $3.21(-7.65,14.07)$ & \\
\hline Yes & & \\
\hline ERAS protocol & Reference & \\
\hline Pre & $-14.64(-19.29,-9.99)$ & $<001$ \\
\hline Post & & \\
\hline Procedure type & reference & \\
\hline Open & $-7.40(-12.21,2.59$ & 0.003 \\
\hline Robotic &
\end{tabular}


medRxiv preprint doi: https://doi.org/10.1101/2020.05.24.20112243; this version posted May 25, 2020. The copyright holder for this preprint (which was not certified by peer review) is the author/funder, who has granted medRxiv a license to display the preprint in perpetuity.

It is made available under a CC-BY-NC-ND 4.0 International license .

Supplementary Table E. Multivariable analysis of the difference in opioid prescriptions given at discharge after prostatectomy

\begin{tabular}{|l|l|r|}
\hline & Difference $(95 \% \mathrm{Cl})$ & P value \\
\hline $\begin{array}{l}\text { Age (every 1-year } \\
\text { increase in age) }\end{array}$ & $-0.29(-0.56,0.025)$ & 0.03 \\
\hline Race & & \\
\hline White & References & \\
\hline Black & $-3.72(-11.58,4.13)$ & 0.35 \\
\hline Others & $-4.49(-13.44,4.46)$ & 0.32 \\
\hline Preop narcotics & & \\
\hline No & Reference & 0.23 \\
\hline Yes & $-11.63(-30.56,7.28)$ & \\
\hline ERAS pathway & & \\
\hline Pre-ERAS & Reference & $<0.001$ \\
\hline Post-ERAS & $10.17(-13.12,-7.22)$ & \\
\hline
\end{tabular}

Supplementary Table F. Multivariable analysis of the difference in opioid prescriptions given at discharge after radical cystectomy

\begin{tabular}{|l|l|l|}
\hline & Difference $(95 \% \mathrm{Cl})$ & P value \\
\hline Gender & Reference & \\
\hline Female & $-1.83(-13.05,9.38)$ & 0.74 \\
\hline Male & $-0.71(-0.49,0.34)$ & 0.73 \\
\hline $\begin{array}{l}\text { Age (every 1-year } \\
\text { increase in age) }\end{array}$ & & \\
\hline Race & References & \\
\hline White & $-2.60(-7.95,5.40)$ & 0.85 \\
\hline Black & $1.12(-9.25,12.80)$ & 0.65 \\
\hline others & & \\
\hline Preop narcotics & Reference & \\
\hline No & $10.58(-5.99,27.17)$ & 0.20 \\
\hline Yes & & \\
\hline ERAS pathway & Reference & \\
\hline Pre & $-7.48(-18.64,3.68)$ & 0.18 \\
\hline Post &
\end{tabular}

